\title{
KEHIDUPAN ETNIS MADURA PASCA KONFLIK DENGAN ETNIS DAYAK TAHUN 1997 DI DESA PAHAUMAN KEC. SENGAH TEMILA KABUPATEN LANDAK KALIMANTAN BARAT
}

\author{
Juwanda 1) \\ Program Studi Pendidikan Sejarah dan Sosiologi Ikip Budi Utomo Malang \\ juwanda@gmail.com \\ Winin Maulidya Saffanah 2) \\ IKIP Budi Utomo Malang \\ wininmaulidyasaffanah@budiutomomalang.ac.id
}

\begin{abstract}
Etnis Madura tidak kembali kedaerah asalnya ada dua faktor yaitu faktor internal dan eksternal faktor internal ialah faktor keluarga dan faktor eksternal adalah faktor mata pencaharian dan lahan. cara beradaptasi Etnis Madura terhadap masyarakat Dayak melalui dua cara yaitu dengan mempelajari bahasa setempat dan silaturahmi atau mengunjungi tempat tinggal warga sekitar. , kondisi Kalimantan Barat saat ini pada tahun 2018 sudah aman dan tentram kembali aturan-aturan yang awal sudah diberlakukan lagi serta kondisi antara etnis Madura dan etnis Dayak sudah tidak ada rasa benci maupun dendam.
\end{abstract}

Kata kunci: konflik, etnis Madura, etnis Dayak

\section{PENDAHULUAN}

Di Kalimantan Barat, konflik yang bernuansa suku, agama, dan ras, lebihlebih menyangkut antar Suku bangsa, bukan hal baru, jejaknya bisa diruntut sejak 1967, saat terjadi anti Tionghoa di kawasan ini. Bahkan lebih jauh lagi, pada 1770-1854, terjadi konflik antar warga Tionghoa, Melayu dan Dayak menurut Kristianus (dalam Siahan 1994:1).Pengamatan cermat menunjukan, sejak saat itu di wilayah ini secara historis banyak diwarnai oleh aksi dan konflik rasial. Warna-warna tadi tampak menjadi gejala, yang selalu berulang dengan interval waktu lebih pendek.

Melihat pada banyaknya jumlah peristiwa yang terjadi, berbagai pendapat pun bergulir untuk menemukan penyebabpenyebab konflik. Menurut Antono (1998:9) Ada tiga argumen tentang pertikaian antara antara Dayak dan Madura, yaitu argumen budaya, ekonomi, dan politik.

Menurut AL Humaidi (2007:188) selama sebelas kali konflik antara Madura Kal-Bar dengan Dayak, tak seorang pun 
dan tak sekalipun Madura kalbar bergabung dengan saudaranya. Dengan demikian, walaupun etnis Madura Kalbar memiliki pengalaman pahit, etnis Dayak tetap memberikan reaksi terhadap etnis Madura Kalbar, begitu juga etnis Melayu yang berhubungan dengan etnis Madura pendatang.

Untuk menghentikan konflik yang berlarut-larut, maka kedua pihak sepakat untuk menyetujui ikrar perdamaian etnis Madura Kalbar kembali bebas melakukan aktivitas sehari-hari bahkan bekerja untuk mencari penghidupan, beraneka ragam pekerjaan yang digeluti oleh etnis Madura di Kalimantan Barat walaupun dengan kondisi yang sangat berbeda, tidak lagi mengkhawatirkan akan adanya serangan susulan dari etnis Dayak, meskipun mereka mempunyai pengalaman yang pahit. Dengan demikian etnis Dayak juga tidak takut akan balas dendam dari Etnis Madura.

Etnis Madura mulai beradaptasi terhadap lingkungan etnis Dayak dengan saling membantu atau gotong royong, $\mathrm{Hal}$ ini sangat terlihat pada saat acara pernikahan dan kematian etnis Madura saling membantu satu sama lain hingga menimbulkan simpati etnis Dayak terhadap etnis Madura, mereka mulai sedikit demi sedikit menggunakan bahasa
Dayak dan sangat jarang menggunakan bahasa daerah mereka sendiri ketika diluar, setidaknya menggunakan bahasa indonesia. etnis Madura melakukan hubungan simbiosis menurut Soekanto (2012:340) yakni hubungan timbal balik antara organisme-organisme hidup yang berbeda spesiesnya. Yang dilakukan etnis Madura saat itu ialah hubungan simbiosis mutualisme, di mana terjadi hubungan saling menguntungkan.

\section{TINJAUAN PUSTAKA}

Pertikaian pada tahun1996-1997 bukan lah pertikaian pertamakali yang dirasakan orang Dayak dengan etnis Madura melainkan sudah kesekian kalinya, tapi setelah kesekian kalinya terjadi konflik dengan orang Dayak maka pada tahun1996-1997 terjadilah konflik besar-besaran antara orang Dayak dengan etnis Madura konflik tersebut terjadi di seluruh Kalimantan Barat, dengan konsekuensi etnis Madura harus pergi dari daerah pedalaman atau daerah asal orang Dayak.

Di Kalimantan Barat, konflik yang bernuansa Suku,Agama, dan ras, lebihlebih menyangkut antar Suku bangsa, bukan hal baru, jejaknya bisa diruntut sejak 1967, saat terjadi anti Tionghoa di kawasan ini. bahkan lebih jauh lagi, pada 
1770-1854, yakni konflik antar warga

Tionghoa, Melayu dan Dayak menurut Kristianus (dalam Siahan 1994:1).pengamatan cermat menunjukan, sejak saat itu di wilayah ini secara historis banyak diwarnai oleh aksi dan konflik rasial. Warna-warna tadi tampak menjadi gejala, yang selalu berulang dengan interval waktu lebih pendek. Pemicu konflik sebenarnya sangat sepele, misalnya menyabit rumput di tanah orang lain (kasus 1997), perkelahian kecil (1982), soal mengganggu istri orang (1992), atau karena persenggolan (1994), perebutan perempuan (1996), dan penagihan hutang (1999). Namun persoalan sepele itu kemudian meluas ke wilayah rawan, hingga menimbulkan kejengkelan, khususnya antara suku-etnis Dayak dan Madura(Kristianus2003:33).

Konflik pertama tahun $1950 \mathrm{di}$ Samalantan-Kabupaten Sambas. Berawal dari perkelahian antara Anyom, warga Dayak Kanayatn, dengan seorang warga Madura. konflik kedua pada tahun $1968 \mathrm{di}$ kampung Terap, Kecamatan TohoKabupaten Mempawah. Yaitu kasus terbunuhnya Camat Sani, warga Dayak Kanayatn oleh Sukrie-seorang warga Madura. Ketiga tahun 1976 seorang warga Dayak di bunuh di Bodok (Kabupaten Sanggau). Keempat pada tahun 1977 di
Samalantan-Kabupaten Sambas (kasus terbunuhnya warga Dayak Kanayatn).kelima di Sungai Pinyuh Kabupaten Mempawah (kasus terbunuhnya Cangkeh, wiraswasta Dayak). Keenam pada tahun 1979 di Samalantan Kabupaten Sambas (kasus terbunuhnya warga dayak di Sindoreng).menurut majalah tempo edisi Juni 1979, 22 orang dinyatakan meninggal dalam konflik tersebut, dan ratusan rumah dibakar. Inilah konflik terbesar pertama diantara kedua etnis.dalam penyelesaian konflik tahun 1979 di buat tugu perdamaian di Samalantan.

Ketujuh tahun 1983 di Sungai Ambawang Kabupaten Pontianak. Berawal dari seorang warga Dayak menampar seorang warga Madura yang menyabit rumput ditanahnya, lalu orang Dayak tersebut dibacok dengan arit hingga tewas.

Kedelapan, bulan November 1993di Gang Apel Kodya Pontianak. Kesembilan, bulan Desember 1994 di Tumbang Titi (Kabupaten Ketapang).Kesepuluh, 28 Desember 1996. Berawal dari Kota Ledo, lalu meluas ke hampir seluruh Kabupaten Sambas.

Konflik kesepuluh tersebut hampir mereda lalu meledak lagi tanggal 15 februari 1997 hingga 28 februari 1997. 
Konflik kesebelas ini terjadi di Kabupaten

Pontianak, Sambas, dan Sanggau.

Gemanya terasa keseluruh Kalimantan Barat(Patebang 1998:79-80).

Pada masa sebelum dan masa kolonial, Kalimantan Barat terpecah-belah dalam peperangan antar etnis Dayak atau populer disebut 'kayau'.ketika itu orang Dayak mengenal politik yang sangat terbatas, mereka hanya berfikir untuk menghabisi orang lain yang masuk dan mencari hasil hutan di wilayah mereka karena dianggap musuh(Kristianus.2009:152)

Melihat pada banyaknya jumlah peristiwa yang terjadi, berbagai pendapat pun bergulir untuk menemukan penyebabpenyebab konflik. Menurut Antono (1998:9) Ada tiga argumen yang dikemukakan komentator lokal untuk menjelaskan pertikaian antara antara Dayak dan Madura, yaitu argumen budaya, ekonomi, dan politik.

Citra tentang orang Dayak dimata etnis Madura, atau sebaliknya turut mempengaruhi sikap dan tindakan yang diambil dalam hubungan kedua suku tersebut(Giring 2004:64).Pencitraan itu berkaitan dengan pecahnya konflik diantara keduanya pada tahun-tahun berikutnya. Untuk itu, dibutuhkan keseriusan pemerintah dalam hal penanganannya.

Selama sebelas kali konflik antara Madura Kal-Bar dengan Dayak, tak seorang pun dan tak sekalipun Madura kalbar bergabung dengan saudaranya, Dayak, memberikan reaksi terhadap Madura kalbar, walaupun mereka memiliki pengalaman pahit, yang sama dengan Melayu dalam berhubungan dengan pendatang baru Madura(Al humaidi 2007:188).

\section{METODE PENELITIAN}

Penelitian ini termasuk jenis penelitian empiris dengan menggunakan pendekatan deskriptif kualitatif. Sedangkan sumber data yang digunakan adalah sumber data primer dan skunder. Metode pengumpulan data adalah wawancara dan dokumentasi. Metode analisis data yang digunakan pada penelitian ini adalah analisis deskriptif.

Sebelum hasil wawancara dan dikuatkan dengan dokumentasi tentang kehidupanetnis Madura terhadap etnis Dayak dianalisa, perlu dilakukan proses pengolahan data terlebih dahulu untuk memisahkan mana data yang relevan dengan tujuan penelitian dan mana yang tidak. Adapun proses pengolahan data dimulai dengan proses sebagai berikut: 
1. Pemeriksaan data (editing)

Dalamtahapan ini, data-data yang dikumpulkan diperiksa ulang, untuk menentukan apakah sesuai dengan fokus pembahasan peneliti. Penelitian ini fokus padakehidupanetnis Madura terhadap etnis Dayak pasca kerusuhan tahun 1997 di Kalimantan Barat. Oleh karena itu, penelitian mencari bahan materi yang berkenaan dengan tema tersebut. Berikutnya, penelitian menggunakan hasil wawancara dan buku-buku yang spesifik membahas tentang kehidupan.

2. Klarifikasi data (classifying)

Berikutnya, data diklasifikasi berdasarkan pembahasan penelitian. Buku-buku, jurnal, artikel dan referensi yang sudah dikumpulkan diklasifikasi menurut pembagian masing-masing yaitu berkaitan dengan kehidupan.

\section{Verifikasi data (verifying)}

Data atau bahan di verifikasi atau diperikasa kebenarannya, siapa penulisnya, tahun ditulis untuk dilihat kemuktahirannya. Untuk melakukan penelitian, peneliti juga membutuhkan bahan/materi yang masih berlaku karena itu lebih diutamakan referensi yang terbaru (paling mutakhir) yang berkaitan dengan tema yang akan diteliti.

4. Analisis data (analyzing)
Karena penelitian ini adalah penelitian lapangan, maka tahapan terakhir adalah menganalisis data-data yang telah diklasifikasikan dan disistematisasikan dengan menggunakan hasil wawancara, kaidah-kaidah, teori-teori dan konsep pendekatan yang sesuai, sehingga dapat memperoleh kesimpulan yang benar.

5. Konklusi data (concluding)

Pada tahap ini, peneliti menyimpulkan hasil analisis dan menemukan kesimpulan tentang bagaimana kehidupanetnis Madura terhadap etnis Dayak pasca kerusuhan tahun 1997 di Kalimantan Barat.

\section{HASIL DAN PEMBAHASAN}

\section{Latar Belakang Etnis Madura Untuk} Tetap Tinggal di Kalimantan Barat

Setelah dilakukan observasi, wawancara dan menguji dokumen secara langsung telah ditemukan dua faktor yang mempengaruhi etnis Madura untuk tetap tinggal di Kalimantan Barat yaitu faktor internal dan faktor eksternal.

a. Faktor Internal

Faktor internal bagi etnis Madura yang tetap tinggal di Kalimantan Barat khususnya di Desa Pahauman Kecamatan Sengah Temila Kabupaten Landak ialah faktor istri yang asli kelahiran Kalimantan 
Barat.secara hukum, dinyatakan dalam Undang-Undang Republik Indonesia Nomor 1/1974, bab I, pasal I bahwa "perkawinan ialah ikatan lahir batin antara seorang pria dan seorang wanita sebagai suami istri dengan tujuan membentuk keluarga yang bahagia dan kekal berdasarkan Ketuhanan Yang Maha Esa". dalam penelitian ini H.M sangat menjaga keharmonisan keluarga, H.M tidak mau jauh dari istrinya ketika terjadi konflik istrinya tidak mau diajak kembali ke tempat asal H.M, ketika konflik terjadi H.M memutuskan untuk mengungsi terlebih dahulu dan kembali setelah suasana kembali aman. H.M mengatakan bahwa:

Dan juga macam isteri saya tu kan asli kelahiran sini di pahauman makanya susah lah maok jauh dari keluarganya .dengan tetangga-tetangga kamek sebetulnya kakak beradik walaupun dia orang Dayak, saya bilang kakak beradik tetanggak tuh kalo ketemu sama-sama menangis ketemu di pasar semua nangis semua, iyaa.(H.M/29/3/2018)

H.M membangun kembali tempat tinggal agar bisa hidup di Kalimantan Barat. Menurut Hartoyo Dkk pada penelitiannya yang berjudul faktor-faktor yang mempengaruhi kesejahtraan keluarga (2015:139) menyatakan bahwa tempat tinggal merupakan salah satu faktor kesejahteraan keluarga. Istri merupakan salah satu alasan etnis Madura untuk menetap di Kalimantan Barat, karena tidak sedikit orang suku asli Madura yang menikah dengan orang suku asli di Kalimantan Barat, seperti informan 1 yang istrinya asli kelahiran Kalimantan Barat dan pada saat pasca kerusuhan informan 1 masih tinggal di tempat kediaman orang tua sang istri atau mertuanya.

Faktor internal selanjutnya, keluarga yang ada di daerah asal mereka tidak menerima akan kedatangan keluarganya yang berada di Kalimantan Barat dikarenakan ketidak mampuan dalam ekonomi dan tempat tinggal mereka, menariknya dalam penelitian ini peneliti menemukan bahwa salah satu informan yang hendak kembali ke daerah asalnya, keluarga B.M tidak dapat menampungnya dikarenakan tanah dari hasil pembagian warisan orang tua informan telah dihabisi oleh keluarga B.M yang berada di Pulau Madura, karena kesabaran dari B.M tanah yang telah dihabisi oleh keluarganya sudah di ikhlaskan dan tidak pernah menuntut kembali permasalahan itu karena takut tejadi perselisihan antar keluarga tradisi carok sangat terkenal di Madura untuk menyelesaikan suatu masalah, dari 
masalah keluarga maupun masalah dengan orang lain.

Menurut Subaharianto dalam bukunya yang berjudul Tantangan Industrialisasi Madura (60.2014) menjelaskan bahwa tindakan carok merupakan manifestasi dari upaya membela dan menjaga harga diri, dengan jalan kekerasan fisik. Dalam hal ini B.M lebih baik mengalah dari pada ada pertumpahan darah diantara keluarganya, oleh sebabitu B.M kembali lagi ke Kalimantan Barat dan mencari tempat tinggal serta pekerjaan demi mempertahankan hidup B.M.

\section{b. Faktor Eksternal}

Mata pencaharian merupakan faktor yang sangat mendominasi tentang alasan etnis Madura untuk tetap tinggal di Kalimantan Barat, menurut Imam Prambudi dalam penelitiannya yang berjudul perubahan mata pencaharian dan nilai sosial budaya masyarakat(2010:7) mata pencaharian adalah pekerjaan pokok yang dilakukan manusia untuk hidup dan sumberdaya yang tersedia untuk membangun kehidupan yang memuaskan (peningkatan taraf hidup).karena etnis Madura sangat rajin dalam bekerja dan tidak sedikit etnis Madura yang menjadi sukses di Kalimantan Barat.

Pulau Madura termasuk dalam jajaran pulau tropis yang suhu udaranya pada musim penghujan berkisar pada angka $28^{\circ} \mathrm{C}$ dean pada musim kemarau rata-rata $35^{\circ} \mathrm{C}$. Oleh karena itu, ketika musim kemarau datang, udara di seluruh Madura menjadi sangat panas dan, biasanya, sumber-sumber air mengering. Di banyak tempat terlihat kumpulan orang desa antri mengambil air di sumur-sumur atau di sumber-sumber air dekat sungai yang masih menyimpan debit air, meskipun mereka harus berjalan beberapa kilometer dari rumah dan harus bersabar menunggu antrian sejak dini hari. Pada musim kemarau, air menjadi barang langka dan sangat berharga bagi orang desa, baik untuk memenuhi kebutuhan rumah tangga maupun aktivitas pertanian (Wiyata,2002:33)

Dengan kondisi daerah asal etnis Madura diatas sangat tidak memungkinkan untuk kembali, karena pada umumnya umumnya mata pencaharian masyarakat di indonesia berasal dari sektor agraris, jadi etnis Madura sebagian besar bermata pencaharian sebagai petani ada pula yang lainnya sperti berdagang atau memiliki toko sembako. Dengan kondisi tanah di Kalimantan Barat yang baik untuk bertani etnis Madura menjadi betah untuk tetap tinggal di Kalimantan Barat. 
Meskipun orang-etnis Madura mempunyai corak agraris, dalam segi pemenuhan kebutuhan pangan, Madura sangat tergantung pada impor beras dari pulau (Subaharianto dkk,2004:41), dengan penjelasan di atas bahwa di pulau Madura walaupun mayoritas masyarakat agraris masih saja kebutuhan beras untuk masyarakat di daerah tersebut tidak memadai, oleh karena itu banyak dari Etnis Madura yang tidak mau bahkan keberatan untuk kembali ke daerahnya.

Menurut salah satu informan bahwa mata pencaharian di Madura cukup sulit, T.N berpendapat bahwa:

Karne e Medureh jiah termasok pencarian sehari-hari memang sakek, apapole seperteh rengtiyah riyah tak tak andik anoh dissah, tak andik lahan pertanian mak gik abeliah pole dessah mak gik ngarep agin keluarga, semen tara keluarga se bede e Medureh, lakar la sakek pencahariennah, mangkanah lebih baik bertahan e kalimantan daripada reng tiyah abelih ka Medureh.

Artinya:

Karne di Madura itu termasuk pencarian sehari-hari memang sangat sakit apa lagi seperti kita itu gak punya anu tidak punya lahan pertanian, masih mau balik ke sana, masih mau mengharapkan keluarga, sementara keluarga yang ada di Madura, memang udah sakit mata pencahariannya, makanya lebih baik bertahan di kalimantan dari pada kita kembali ke Madura.(/T.R/31/3/2018)

Lahan adalah faktor lain yang melatar belakangi orang-etnis Madura untuk tetap tinggal di Kalimantan Barat karena lahan atau tanah merupakan hal yang sangat penting bagi masyarakat agraris. Sejak lahir sampai meninggal dunia, manusia membutuhkan tanah untuk tempat tinggal dan sumber kehidupan, dalam hal ini, tanah mempunyai dimensi ekonomi, sosial, kultural, politik dan ekoligis (Limbong,2012:2)

Begitu pentingnya lahan tempat tinggal bagi orang-orang etnis Madura bahkan manusia, karena tempat tinggal atau rumah adalah tempat bernaung, sangat jarang ditemukan etnis Madura yang tidak memiliki tempat tinggal di Kalimantan Barat, berbeda dengan kondisi di daerah asal mereka yaitu Pulau Madura yang masih banyak etnis Madura yang hidupnya masih gelandangan atau tidak memiliki tempat tinggal, bahkan pekerjaannya masih mengemis, dengan kondisi demikian, menetap untuk ti nggal di Kalimantan Barat adalah pilihan yang baik bagi masyarakat pekerja keras etnis Madura.

\section{Adaptasi Etnis Madura}


Dalam penelitian ini ada beberapa cara etnis Madura melakukan adaptasi terhadap lingkungannya pasca konflik pada tahun 1997 dari mempelajari Bahasa daerah setempat, melakukan pekerjaan bersama, silaturahmi dan ada juga dengan cara mencari teman lamanya yang masih tinggal di sekitar lingkungannya seperti yang dilakukan oleh R.K dia langsung kembali bekerja bersama teman lamanya serta R.K juga sempat menanyakan tentang anak istrinya yang di bunuh oleh orang yang satu suku dengan teman lama informan R.K.

\section{a. Adaptasi Dengan Cara Berbahasa}

Adaptasi manusia sendiri diartikan sebagai aktivitas-aktivitas manusia dalam mencampurtangani lingkungan dalam rangka mempertahankan kehidupannya dengan tingkat budaya yang dimiliki (Steward, 1955

dalam

Ritohardoyo,2005:35), daerah Kalimantan

Barat daerah yang memiliki dua kebudayaan asli yaitu kebudayaan yang berasal dari etnis Dayak dan kebudayaan yang berasal dari masyarakat Melayu, dalam penelitian ini etnis Madura melakukan adaptasi terhadap etnis Dayak serta kebudayaannya, mempelajari bahasa Dayak setempat adalah salah satu kebudayaan etnis Dayak yang dipelajari oleh etnis Madura untuk beradaptasi terhadap lingkungannya, seperti yang dilakukan oleh T.R dan S.N, S.N berpendapat bahwa:

Yaa kalo seperti kita itu kan, boleh dikatakan $50 \%$ bahasa dayak itu bisa yaa bahasa dayak(S.N/8/4/2018).

Begitu juga T.R menyatakan :

Abit sebenderreh karna faktor lingkungan se bedeh, karna bekto jiah benni satu tempat beni satu kennengan termasok deri benyak kennengan, deri Kerohok, Menjalin, Pahuman, Senakin ajiyah edelem bektoh setaon jiyah reng tiyah roh gitak apa benyak pendapat-pendapat se gitak padeh gik gitak sepaham jih bektu jiah se anuh, tak langsung reng tiyah bise beradaptasi abit sebenderreh gik ahakpihak make la neng-neng satu tempat dia gik merasa areh oreng Pahuman Pareh oreng senakin areh oreng Kerohok, abit untok bersatu jiyah sebenderreh makan bektoh sekitar telo taon pak taon mungkin on-laon engkok ajer bahasanah die lah dan akhirreh akor lah engkok ben lingkungan setrempat.

Artinya: Lama sebanarnya, karena sih faktor lingkungan yang ada, karena waktu itu ter apa, bukan dari satu tempat, bukan satu kediaman, termasuk dari banyak kediaman dari Kerohok, Menjalin, Pahauman, senakin itu di dalam 
waktusetahun itu, kita itu belum apa banyak pendapat-pendapat yang tidak sama, masih belum sepaham ini, lama waktu itu yang anu, tak langsung pas kita bisa beradaptasi anu, lama sebenarnya masih berpihak-pihak walaupun dijelaskan diam satu tempatdia merasa masih ini orang Pahauman, ini orang Senakin, ini orang Kerohok itu lama untuk anu itu, untuk proses satu aja makan waktu sampai tiga tahun sampai empat tahun mungkin pelan-pelan saya belajar bahasa dia dan akhirnya sedikit-sedikit saya akur dengan lingkingan setempa $t(T . R / 31 / 3 / 2018)$.

Menurut Sitohang dalam penelitiannya yang berjudul Penggunaan Bahasa Daerah Sebagai Bahasa Pengantar Di Kelas Rendah Sekolah Dasar Di Kota Palangkaraya (2017:131).Bahasa dalam bentuk apapun ialah proses aktualisasi dari keinginan, emosi, dan pikiran-pikiran manusia agar orang lain dapat memahaminya. Bahasa menjadi alat komunikasi antara individu satu dan individu lainnya. Mereka yang menggunakan bahasa yang sama merasakan suatu ikatan batin sebagai suatu kelompok kesukuan, kebangsaan, dan sebagainya.

Interaksi antar individu bisa menjadi tertata sehingga individu tersebut merasa nyaman dalam berinteraksi dan bisa menjadi lebih akrab antara satu sama lain, penggunaan bahasa tersebut juga dapat memudahkan dalam beradaptasi bahkan melakukan pekerjaan terutama terhadap warga baru yang masih di asingkan oleh masyarakat sekitar seperti pada fokus penelitian ini adalah etnis Madura yang Masih tinggal di Kalimantan Barat, pada saat kerusuhan mereka masih hidup berkelompok, maka dalam berbahasa pun mereka menggunakan bahasa daerah mereka yaitu bahasa Madura, setah konflik antara etnis Dayak dan Etnis Madura terjadi pada tahun 1997 mereka sudah banyak yang menyebar akan tetapi ada pula yang masih ingin hidup berkelompok dengan teman atau kerabat lamanya.

Menurut Wibowo dalam penelitiannya tahun 2001 halaman 1 menyatakan bahwa, bahasa adalah sistem simbol bunyi yang bermakna dan beraktualisasi (dihasilkan oleh alat ucap) yang bersifat arbiter dan konvensional yang didipakai sebagai alat berkomunikasi oleh sekelompok manusia untuk melahirkanperasaan dan pikiran. Dari pengertian di atas dapat disimpulkan bahwa mempelajari bahasa daerah sekeliling atau tempat tinggal kita berada sangat diperlukan sebab kita tidak bisa mengetahui orang-orang di daerah sekitar 
kita apakah dia bisa berbahasa indonesia, karena di desa Pahauman pada pasca kerusuhan tahun 1997 masih sedikit yang berpendidikan, dapat dilihat pada BAB IV tentang kondisi pendidikan masyarakat Kab Landak.

Di daerah Kalimantan Barat khususnya di desa Pahauman etnis Dayak masih banyak warga etnis Dayak yang tidak lancar berbahasa indonesia, maka dari itu etnis Madura yang tinggal di Desa Pahauman harus bisa berbahasa Dayak demi untuk bisa bersatu dengan suku-etnis Dayak sekitar agar tercipta lingkungan kekeluargaan yang baik.

Pekerjaan merupakan suatu usaha yang dilakukan oleh manusia untuk bertahan hidup dalam hal ini etnis Madura pada saat pasca konflik 1997 melakukan pekerjaan demi bisa bersatu kembali terhadap etnis Dayak, tidak sedikit orangetnis Madura di Kalimantan Barat ikut etnis Dayak bekerja demi memperbaiki hubungan agar tecipta lingkungan yang damai.

b. Adaptasi Dengan Cara Silaturahmi Atau Mengunjungi Rumah Warga Seakitar.

Etnis Madura juga melakukan silaturahmi terhadap masyarakat lingkungan sekitar sebagai cara untuk mendekatkan diri terhadap lingkungan seperti yang dilakukan oleh S.N bahwa: Aa yaa kita apa, ya cara membaur yaa kita bukan di tempat konflik lagi, sudah daerah lain rasanya terutama sini kan, boleh dikatakan caranyakan membaur kembali terhadap beliau yang pernah bentrok sama kite kan gitu, membaur kembali saat apa yah kita hidupkan kembali aturan yang awal, pembauran yang awal gitu dikembalikan lagi, ini seperti mengadakan apaya sosialisasi pertemuan atau semacam pendekatan artinya melewati ketemu atau silaturahim atau ketemu kerja kan gitu(W/S.N/8/4/2018).

Dengan membaur, S.N bisa menghidupkan aturan yang awal sebelum konflik terjadi untuk menghindari ancaman-ancaman tentang penyerangan etnis Dayak terhadap orang-etnis Madura, dengan cara itu informan melakukan adaptasi. Karenaadaptasi menurut Rahmayanti(2014:23) dalam penelitiannya yang berjudul Adaptasi Masyarakat Kota Rawan Bencana adalah usaha dari makhluk hidup (terutama manusia) untuk bereaksi terhadap keadaan luar/lingkungan yang berubah termasuk intervensi, gangguan dan ancaman. maka dari itu tidak sedikit etnis Madura yang melakukan silaturahmi terhadap masyarakat sekitar desa Pahauman. 
Menurut Soeparman dalam Soeparwoto(2005:151-153) memperkuat pendapat dari Julian H.Steward bahwa pendapat empat prinsip yang terkait dengan penyesuaian diri atau proses adaptasi yaitu:

a) Penyesuaian diri adalah proses penyelarasan antara kondisi diri atau individu sendiri dengan sesuatu objek atau perangsang melalui kegiatan belajar.

b) Proses penyesuaian diri selalu terjadi interaksi antara dorongan-dorongan dari dalam diri individu dengan perangsang atau tuntutan lingkungnan sosial.

c) Melakukan penyesuaian diri diperlukan adanya proses pemahaman diri dengan lingkungannya sehingga terwujud keselarasan, kesesuaian, kecocokan, atau keharmonisan interaksi diri dan lingkungan.

d) Penyesuaian diri selalu berproses dan berkembang secara dinamis, sesuai dengan dinamika lingkungan hidup dan perkembangan dorongankeinginan individu.

Pendekatan-pendekatan informal diantaranya yang bersifat kekeluargaan diyakini akan lebih efektif. Gagasan pendekatan informal ini secara umum menginginkan bagaimana etnis Madura dapat membangun citra positif terlebih dahulu kepada etnis Dayak, sehingga pada gilirannya dapat meyakini masyarakat Etnis Dayak , sehingga keberadaan etnis Madura di daerah mereka tidak akan menimbulkan konflik kembali dan mereka sama-sama menginginkan kehidupan yang sejahtera dan tentram sebab mereka masih saling membutuhkan tenaga maupun pikiran.

\section{Kehidupan Etnis Madura Saat Ini di Kalimantan Barat Tahun 2018 \\ Kita ketahui bahwa kondisi} Kalimantan Barat saat ini sangatlah aman dan damai seperti yang dikatakan oleh semua informan pada saat penelitian ini dilakukan tentang kondisi saat ini di kalimantan barat bahwa tidak ada masalah lagi antar suku pendatang Madura dengan etnis Dayak, meskipun di daerah Sambas masih belum bisa menerima kedatangan Etnis Madura di daerahnya, walaupun demikian daerah di luar sambas dan khususnya kota pontianak secara alamiah sudah menganggap bahwa pertikaian tersebut selesai bahkan H.M mengatakan Ye kenyataannye aman yetakade ape-ape lagi dah, sekarang biase lagi macem dulu sebelum terjadi aman, kite ketemu dengan orang kampung, same-same akrab lagi 
teman-teman yang baek lagi, di mobil, di pasar dimnane kita macem biase-biase saja lagi lah, itu namanya suatu musibah itu tidak bisa di kehendaki oleh manusia, itu semue kehendak allah subhanahuwataala, itu untuk, make saya tuh kalo mnurut peribadi saya, ndak ade bergantung ini musibah ni memang orang Dayak, ndak ada itu yang menentukan... allah(H.M/29/3/2018).

Dan begitu juga R.K yang berpendapat tentang keamanan, bahwa:

Yee mon setiyah enjek, biasa, aman

Artinya: yaa kalo sekarang ndak, biasa, aman(/R.K/13/5/2018).

Dua informan di atas yang menyatakan tentang keamanan Kalimantan barat dan sudah saling melupakan tentang perselisihan pada tahun 1997 yang lalu, dan mereka saling akrab satu sama lain.

Rasa percaya saling percaya dan harmoni antara kelompok dan golongan masyarakat merupakan faktor yang penting untuk menciptakan rasa aman dan damai. Peristiwa pertikaian dan konflik antar kelompok dan golongan yang mewarnai perpolitikan merupakan pertanda rendahnya saling percaya dan tiadanya harmoni didalam masyarakat. Olehkarena itu agar tercipta rasa aman dan damai secara berkelanjutan, rasa percaya dan harmoni antar kelompok harus terus dipelihara dan dibangun, serta pertikaian dan konflik perlu untuk ditangani dan diselesaikan (Mamangkey,2016:2)

Dengan demikian rasa saling percaya antar individu dan kelompok harus dijaga dan dibangun sebaik mungkin agar tidak terjadi lagi konflik atau pertikaian antar suku seperti yang terjadi sebelumnya karena kondisi saat ini sudah menjadi kondisi yang di ingun kan antar kedua suku yang terlibat dalam konflik tersebut.

Ketika peneliti melakukan observasi, kondisi tempat kejadian di Desa pahauman sangat sejahtera bahkan peneliti sempat menemukan petugas kantor desa yang mengatakan bahwa sampai saat ini masih sangat akrab dengan etnis Madura yang berada di Desa Pahauman tersebut, karena permasalahan yang lalu sudah di lupakan dan merka yakin bahwa kejadian tersebut tidak akan terulang lagi, itu adalah salah satu bukti kondisi sosial antara etnis Madura dan Etnis Dayak sudah rukun dan sejahtera.

Peneliti juga menemukan sumber lain tentang bukti bahwa antara etnis Dayak dan Etnis Madura sudah hidup sejahtera, ketika peneliti telah melakukan ibadah solat di Masjid bertemu dengan bapak Wahid, yang menjadi imam di masjid Desa Pahauman informan tersebut 
mengatakan bahwa tidak pernah ada lagi perselisihan setelah kerusuhan tahun 1997saya pindah dari Ngabang itu pas sebelum kerusuhan, tiga bulan sebelum kerusuhan saya udah tinggal di sini, dan itu orang-orang Dayak sudah nghalang i jalan pake drum-drum itu di Ngabang sana, dan pada tahun 1999 ada banyak etnis Madura yang kembali ke sini lagi ada yang tetap tinggal ada juga yang menjual itu tanah dan tempat tinggalnya, pernyatan dari bapak H.Wahid tersebut adalah bukti bahwa kesejahteraan masyarakat yang tinggal Desa Pahauman tersebut.

\section{Resolusi konflik}

Ada dua buah rumah pas di sebelah utara dan selatan masjid di pasar Desa pahauman yang menjadi bukti bahwa kerusuhan di Desa Pahauman telah terjadi, rumah yang di sebelah utara tersebut sampai saat ini belum pernah di perbaiki bahkan warga sekitar tidak ada yang berani mendiami rumah tersebut sampai saat ini,bahkan pemilik rumah pernah menawarkan untuk menjual rumah tersebut tetapi tidak ada satu orangpun yang mau membelinya pemilik rumah tersebut adalah warga asli Madura yang mengungsi ketika terjadi konflik antara etnis Madura dan Etnis Dayak pada tahun 1997.
Pasca kerusuhan tahun 1997 ditemukan tujuh mayat yang membusuk di dalam rumah sebelah Masjid pasar Pahauman tersebut, mayat tersebut adalah warga etnis Madura yang meninggal akibat konflik tersebut, ketujuh mayat tersebut ditemukan ketika sudah beberapa minggu konflik itu mereda saat salah satu warga yang ingin mencari barang-barang yang ada di dalam rumah tersebut dan mencium baubusuk awalnya dan menemukan mayat-mayat tersebut(H.Wahid,hasil wawancara 28-062018)

Sejarah konflik di Kalimantan Barat tidaklah terjadi hanya sekali tapi sudah 15 kali sejak tahun 1950-1997 dengan demikian tentu Negara sangat menginginkan perdamaian antar suku yang terlibat dalam konflik, pemerintah telah melakukan berbagai cara untuk menyatukan kembali suku-suku yang terlibat dalam pertikaian etnis, dari menyediakan tempat untuk mengungsi serta kebutuhannya, dan perundingan antar para pengetua suku yang ada di Kalimantan Barat.

Ralf Dahrendorf yang memiliki penjelasan bahwa semua perubahan sosial yang dialami manusia merupakan hasil dari konflik kelas di masyarakat. Dahrendorf sangat yakin bahwa konflik 
dan pertentangan menjadi bagian-bagian hidup masyarakat.

Upaya pemerintah dalam penyediaan lahan untuk tempat mengungsi tidaklah mudah namun juga mengalami hambatan. Menurut septi satriani dalam penelitiannya yang berjudul Jalan Panjang Menuju Perdamaian(2008:128), bahwa ada beberapa kasus, sebut saja, orang-orang Cina yang ada di sekitar lokasi tempat tinggal etnis Madura(melalui model pemberdayaan) yang lantas memilih untuk eksodus saja, karena takut hidup berdekatan dengan etnis Madura. Sedangkan, di Bhakti Suci, Gambut tidak terlalu tebal, tapin setempat membuat syarat agak ketat, antara lain: kalau ada penduduk Madura yang sekali berbuat onar, maka harus di usir. Bahkan di Desa parit Pelita, masyarakat setempat menyatakan keberatan dengan rencana kedatangan transmigrasi asal Madura, sehingga mengakibatkan proses relokasi menjadi agak terlambat.

Dengan demikian pemerintah merasa ada kesulitan saat mengurus pengungsian dari Etnis Madura yang hendak mengungsi, maka suku-etnis Madura yang terlibat dalam konflik yang hendak mengungsi dilarikan ke Bataliyon Militer atau asrama tentara untuk sementara waktu.
Cara selanjutnya yang dilakukan oleh pemerintah dalam menyatukan etnis di Kalimantan Barat adalah mengadakan suatu perundingan dan mempertemukan tokoh-tokoh dari suku-suku yang terlibat dalam konflik yaitu tokoh-tokoh dari etnis Dayak, melayu dan Madura, karena hubungan sosial antar etnis di Kalimantan Barat pada saat itu masih berlangsung tidak baik maka dilakukan lah sebuah perundingan di suatu tempat yang telah disediakan oleh pemerintah untuk sebuah pertemuan yang dinanti-nantikan oleh etnis Madura demi keamanannya.

Menurut Cahyono dkk dalam bukunya yang berjudul Konflik KALBAR Dan Kalteng(2004:106)konflik serta kerusuhan umumnya diselesaikan melalui perundingan antar pimpinan mereka dengan pengawasan pemerintah. Namun, tampaknya model ini hanya menyelesaikan konflik yang terjadi, akan tetapi tidak menyelesaikan akar dari konflik tersebut.perdamaian yang dibuat antarkelompok dengan upacara formal merupakan perdamaian yang semu sifatnya.

Dengan diadakannya perundingan dan mempertemukan tokoh-tokoh antar etnis tidak menjamin akan berakhirnya konflik dan akan terjadi konflik susulan dengan demikian maka negara tidak 
memiliki peran dalam peeroses resolusi konflik tersebut. Namun hal itu semua dimaksudkan sebagai upaya pemerintah melakukan rekonstruksi dalam hubungan antar etnis, yang diharapkan dimana semua pihak dapat belajar dari pengalaman sekaligus mampu merakit hubungan sosial secara damai.

Bupati burhanudin yaitu bupati Kabupaten Sambas tidak peduli akan saran dari pemerintah tentang perundingan antar tokoh tersebut, tetapi ia lebih memilih secara alamiah. Dan menurut Prof.Dr.Sjarif Ibrahim Alqadrie (2004) bahwa atas dasar argumentasi inilah maka, mereka berpikir bukan kah lebih baik bila segalanya dikembalikan secara proses alamiah, namun tanpa menimbulkan konflik lagi.

Proses alamiah yang dimaksudkan adalah membiarkan etnis Madura dan Etnis Dayak saling hidup berdampingan tanpa melakukan perundingan atau pertemuan antar tokoh-tokoh masyarakat baik dari etnis Madura maupun Etnis Dayak sebab dari perkumpulanperkumpulan tersebut akan membuat mereka risih dan damai itu hanya berlaku saat ada perundingan atau perkumpulan antara tokoh-tokoh masyarakat. Jadi proses alamiah dengan hanya pemerintah memberikan pengamanan pada titik-titik tertentu untuk menjaga masyarakat yang terlibat dalam konflik yang hidup saling berdampingan antar suku tersebut.

Proses tersebut tampaknya berhasil sehingga sejak pasca konflik di tahun 1997 hingga saat ini tidak lagi terjadi konflik dan kondisi Kalimantan Barat sedikit demi sedikit kembali normal semula tanpa ada pertikaian atau ketegangan antar etnis kembali.

Dari beberapa peroses diatas adalah upaya pemerintah untuk memersatukan warga masyarakat Indonesia agar bisa hidup dengan tenang, makmur dan sejahtera demikian juga kehidupan yang di inginkan oleh warga masyarakat Indonesia walau pun masih ada yang dendam atau trauma akan konflik yang telah terjadi tersebut, akan tetapi itu tidak menjadi masalah bagi pemerintah karena lebih banyak masyarakat yang menginginkan perdamaian demi kelancaran hidup, bahkan sifat dendam dan trauma akan menyakitkan diri mereka sendiri, walau pun terjadi perselisihan masyarakat masih bisa mengatasi sendiri.

\section{KESIMPULAN}

Berdasarkan paparan data dan analisa data yang telah dilakukan di atas, tentang Kehidupan Etnis Madura 
Terhadap Etnis Dayak Pasca Kerusuhan Tahun 1997 di Desa Pahauman Kec. Sengah temila Kab. Landak Kalimantan Barat, maka dapat di simpulkan sebagai berikut:

1. Latar belakang etnis Madura untuk tetap tinggal di Kalimantan Barat pasca konflik tahun 1997 di Desa Pahauman Kec. Sengah Temila Kab. Landak ada dua faktor yaitu faktor internal dan faktor eksternal.

a. Faktor internal adalah faktor yang berasal dari diri pribadi dan juga keluarga, istri bagi suami bagi etnis Madura adalah hal yang berharga untuk di tinggalkan kembali ke daerah asalnya, maka istri etnis Madura yang asli kelahiran Kalimantan Barat tidak sedikit, hal itu merupakan hambatan bagi etnis Madura yang hendak kembali kedaerah asalnya pasca kerusuhan.

b. Faktor eksternal adalah faktor yang berasal dari luar diri pribadi manusia seperti kebutuhan hidup, mata pencaharian sangatlah penting bagi manusia untuk memenuhi kebutuhan hidup, apa lagi bagi Etnis Madura yang sangat terkenal dengan pekerja keras walaupun merantau bagi mereka adalah hal yang sangat biasa demi pekerjaan, karena di pulau
Madura sangat lah sulit untuk menemukan pekerjaan seperti di Kalimantan Barat. Begitu juga lahan tempat tinggal di Madura, bagi mereka yang telah lama meninggalkan Pulau Madura sejak lama akan sangat kesulitan untuk menemukan lahan untuk tinggal kembali pasca konflik 1997 di Desa Pahauman Kec. Sengah Temila Kab. Landak Kalimantan Barat.

2. Cara etnis Madura beradaptasi pasca konflik 1997 di Desa Pahauman Kec. Sengah Temila Kab. Landak Kalimantan Barat ada dua cara yaitu cara yang pertama dengan mempelajari daerah setempat karena setelah hidup berdampingan dengan etnis Dayak pekerjaan pun akan berdampingan dengan etnis Dayak dan cara yang kedua dengan melakukan silaturahmi terhadap lingkungan sekitar, agar situasi dan kondisi terasa lebih nyaman.

3. Kondisi sosial Kalimantan Barat saat ini tahun 2018sangatlah aman dengan upaya pemerintah menerjunkan aparat keamanan untuk menyelesaikan konflik padasaat itu dan juga penyedian tempat mengungsi sementara dari pemerintah, maka kondisi saat antara 
kedua suku berdampingan sudah aman dan situasi tenang hingga saat ini etnis Madura yang tinggal di Kalimantan Barat merasa aman dan tentram.

\section{Saran}

1. Bagi Masyarakat

Hendaknya saling menghargai dan menghormati walaupun berbeda suku, ras maupun keyakinan jangan saling menjelekkan dan menjatuhkan atau memandang jelek terhadap perbedaan sebab hal-hal tersebut bisa menyebabkan perpecahan dalam hidup bermasyarakat dan menimbulkan pertikaian hingga terjadi konflik kembali, maka hindari hal-hal tersebut.

\section{Bagi Pemerintah}

Hendaknya pemerintah memberikan bimbingan terhadap masyarakat tentang perbedaan suku agar mereka yang hidup saling berdampingan dengan yang berbeda suku merasakan tambah erat tali kekeluargaannya dan tidak ada diantara mereka yang menginginkan salah satunya untuk pergi dari lingkungannya dan saling membenci, pemerintah juga harus sering memperhatikan daerah-daerah terpencil seperti desa Pahauman yang rawan akan terjadinya konflik maka dari itu seringseringlah menerjunkan aparat keamanan untuk berpatroli kepada daerah tersebut.pemerintah juga harus memberikan sangsi yang sangat tegas terhadap masyarakat yang berbuat onaragar masyarakat takut untuk melakukan hal-hal yang tidak wajar untuk berbuat onar, guna menciptakan kedisiplinan terhadap suatu lingkungan dan menghindari hal-hal yang tidak diinginkan.

\section{DAFTAR RUJUKAN}

Achidayat, Anto. 1989. Huungan antar Golongan Etnik di Indonesia: suatu Studi Kasus di Kalimantan Barat, dalam: Interaksi Antar Etnik di Beberapa Propinsi di Indonesia. Jakarta: Dirjen Kebudayaan, Direktorat Sejarah dan Nilai Tradisional, Proyrk IPNB, Depdikbud.

Alqadrie, Syarif Ibrahim, (1990). "Pembangunan, Ketergantungan, dan Kesadaran Etnik Perspektif Teoritis dan Realita." Jurnal IImu Politik, no 10.

Ali, M \& Asrori,M. (2012). Psikologi remaja. Jakarta: Bumi Aksara.

Alo Liliweris, (2005). Prasangka dan Konflik:Komunikasi Lintas Budaya Masyarakat Multikultural.Yogyakarta: PT LKIS Printing Cemerlang

Arikunto, Suharsimi. Prosedur Penelitian"Puatu Pendekatan Praktik" Jakarta:RinekaCipta,2013.

Arkanuddin. 2006. "Menelusuri Akar Konflik Antar Etnik Khususnya Dayak dan Madura di Kalimantan Barat". Proyeksi Jurnal IImu-IImu Sosial dan Humaniora. Volume. 10. No. 3. 2006. HIm. 223-234. 
A.S. Susanto. 1985. Pengantar Sosiologi Sosial, Bandung: PT Remaja Rosdakarya.

Berger, Peter \& Thomas Luckman. 1990. Tafsir sosial atas kenyataan. Jakarta:LP3ES.

Berlin Sibarani. (2004), Bahasa, Etnisitas dan Potensinya Terhadap Konflik. Medan: Jurnal Harian, Universitas Negri Medan.

Cahyono, Tryatmoko, Adam, Satriani.2008. Konflik Kalbar dan Kalteng, Jalan Panjang Meretes Perdamaian.Jakarta: Pustaka Pelajar.

Coakley, J. (2001). Sport in Society: Issue and Controversies. New york: Mc.Graw-Hill

De Graf, H.J. dan Th. G. Th Pigeaud. 1989, Kerajaan-Kerajaan Islam di Jawa: Peralihan dari Majapahit ke Mataram. Jakarta: grafiti pers.

De Jonge, $H . \quad$ (ed.). 1989. Agama,kebudayaan, dan Ekonomi. Jakarta : rajawali

De Jonge,H 1989. Madura Dalam Empat Zaman:Pedagang, Perkembangan Ekonomi, dan Islam. Jakarta: Gramedia.

Dhofier, Z. 1994.Kepemimpinan Kyai:Kasus Pondok Pesantren Tebu Ireng Jombang. Malang: Kalimasadha Press.

Edi Petebang, 1998. Dayak Sakti Ngayau, Tariu, Mangkok Merah: konflik Etnis di Kalbar. Pontianak: Institut Dayakkologi.

Gerungan, W. A. (2003). Psikologi Sosial. Jakarta: PT Eresco Bandung.
Gerungan, W. A. (2004). Psikologi Sosial. Bandung: PT Refika Aditama.

Hasan Basri Ismail. Adaptasi Sosial Mahasiswa Asal Tidore di Kelurahan Titiwungen Selatan Kota Manado. Jurnal holistik Tahun VII No. 15/Januari, 2015

Jawa Post,. "Konflik Antar Suku Dayak dan Madura". Jawa Post, 16 April 2008.

Jhon Haba. "Etnisitas Sosial dan Konflik di Kalimantan Barat" Jurnal Masyarakat \& Budaya, volume 14, No. 1, Tahun 2012.

Maguire, J., et al (2002), Sport World: A Sosiological Perspective.. Campaign: Human Kinetics

Nazir. (1998). Metode Penelitian. Jakarta : Rineka Cipta.

Noor, Juliansyah (2011), MetodologiPenelitian: Skripsi, Tesis, Disertasi, Dan Karyallmiah, Jakarta: Kencana.

Nugroho, Heru, "Konstruksi SARA, Kemajemukan, dan Demokrasi," Jurnal IImu-IImu Sosial, no 40 /XXII/1999.

Pieris, John.2004.Konflik Maluku Konflik Peradaban. Jakarta: Yayasan Obor.

Riwut. 2007. Kalimantan Membangun Alam dan Kebudayaan. Yogyakarta: NR Publishing.

Ruslikan., 1999. Sekolah di Masyarakat Pedalaman:Kajian Fenomenologi Pengadopsian Sekolah di Kalangan Suku Dayak Ngaju Kalimantan Tengah. Disertasi Tidak di Publikasikan. Surabaya: Program Pasca Sarjana Universitas Airlangga. 
Ruslikan.,"Konflik Dayak Madura di Kalimantan Tengah: Melacak akar Masalah dan Tawaran Solusi", Jurnal Tentang masyarakat, Kebudayaan dan Politik, tahun XIV, Nomor 4, Oktober 2001, 1-12.

Siahan, Hotman. Madura, Akulah Darahmu. Kompas, 15 februari 2003.

Sudagung, Hendro Suroyo. 2001.,mengurai pertikaian etnis:Migrasi Swakarsa Etnis Madura ke Kalimantan Barat.Jakarta, ISAI.

Soekanto, S.(2012). Sosiologi Suatu Pengantar. Jakarta: Rajawali Pers.

Soemardjan, Selo., 2001. Konflik Antar Suku di Indonesia. Jakarta: Yayasan IImu-IImu Sosial.

Soerjono Soekanto, 1975. Pengetahuan Kalangan Hukum di DKI terhadap Hukum dan Kependudukan.jakarta: BKKBN.

Subaharianto, A. (2004) api di Tanah Raja: Kajian Antropologi terhadap Radikalisme Petani Jenggawah di Kabupaten Jember 1995. Yogyakarta:Tesis S2, Program Pascasarjana UGM.

Sugiyono,MetodepenelitianKuantitatif Kualitatifdan R\&D, Bandung: Alfabet, 2011.

Suparlan, Parsudi, "kerusuhan Sambas" Jurnal Polisi Indonesia, No 2, Tahun 2, April-September 2000.

Tojjib, Mohammad. 1998. "Kiai dan Kesalehan Pembangunan: studi tentang Kepemimpinan Kharismatik dan Partisipasi Kiai dalam Pembangunan", Skripsi Jurusan Antropologi Fakultas Sastra Unifersitas Udayana, Denpasar.
Wiyata, A. Latief. 1990. "PerubahanPerubahan Sosial yang Mingkin Terjadi pada Masyarakat Madura dalam Era Industrialisasi," Makalah Simposium Madura Menuju Industrialisasi, Pamekasan, 23-24 Juni.

Woods, R. B (2007). Social Issue in Sport. Champaign, Illinosis: Human Kinetic 